\title{
Web 2.0. Örgütlerde Etkili Bir Şekilde Kullanılabilir mi?
}

\section{Mustafa SAĞSAN ${ }^{*}$ (Çev.)}

\begin{abstract}
Öz
Internetin, örgütlerin üst ve orta düzeylerinde gerçekleşen yönetsel çalışmaları kolaylaştırdığı ve girişimci yerel ağların (intranet) uygulamalarına dönüştürülebileceği yönünde iyi olduğu konusunda ortak bir anlayış bulunmaktadır. Bilginin dağıtımı konusundaki en son moda, web günlüklerini (blogs), wiki'leri ve RSS gibi çeşitli araçları içeren Web 2.0. olgusudur. Bu çalışma, kısaca bilginin işlenmesinde kullanılan daha resmi ve geleneksel araçlar ile Web 2.0 olgusu arasındaki ilişkiyi anlatmaktadır. Çalışma, Web 2.0. olanaklarının Internette büyüyeceği ve gelişeceği sürede, kurumlardaki Web 2.0.'In kullanımının, yedek bir hizmet olarak değil, kurumların mevcut hizmetlerine ek olarak dikkatli bir şekilde planlaması gerektiği ile sonuçlanmaktadır.
\end{abstract}

\section{Web 2.0. Tanımlanabilir mi?}

Ulusal ve ticari yayınevlerinden ve İnternet'te yapılan yorumlardan hareketle, Web 2.0.'ın tanımının yapılıp yapılamayacağı sorusuna verilecek cevap, muhtemelen "hayır" olacaktır, fakat İnternet'in çok hızı bir şekilde büyümesi de (bu tanımlamayı gereksindirmesi bakımından) gözardı edilemeyecek bir olgudur. Kişisel konu etiketlemesi (folksonomy) tarafından desteklenen web günlükleri (blogs), wikiler (wikis) ve karma yazılımlar gibi unsurlardan oluşan Web 2.0'ın tüm göstergelerindeki ortak nokta olan demokratikleşme, prensip olarak herkesin herkesle iletişim kurabilmesi ve paylaşılmış alanlara katkı sağlayabilmesidir. Ancak (Web'in babası olarak bilinen) Tim Berners-Lee konuyla ilgili yeni bir şeyin görülmediğini söylemektedir. Ona göre, "eğer size yönelik hazırlanan Web 2.0, web günlükleri ve wikilerden oluşuyorsa, o zaman

“ Öğr. Gör.; Başkent Üniversitesi Iletişim Fakültesi Bilgi Belge Yönetimi Bölümü Bağlıca Kampusu Eskişehir Yolu 20. km. Ankara (msagsan@baskent.edu.tr) 
bu insanla insan arasındadır. Ancak öteden beri Web'den umulan da zaten budur" (Anderson, 2006). Ayrıca Berners-Lee Web günlüklerinin, Web'deki en büyük tehlikelerden birisi olduğunu söyleyerek "Web'in doğruların yayıldığı yer olmaktan ziyade, doğru olmayanların dağılmaya başlandığı yer olduğu yönünde büyük bir tehlike vardır" (Johnson, 2006) sözüyle, bu hareketin karanlık yüzüne dikkat çekmektedir.

Web 2.0.'a yönelik iddialar ilk olarak O'Reilly Medya adlı şirketin Yönetim Kurulu Başkanı olan Tim O'Reilly'nin katıldığı (2005) MediaLive International konferansındaki beyin fırtınası oturumunda ortaya atılmıştır. Bu toplantıda O'Reilly Web 2.0.'a yönelik olarak yapılan açıklamaları aydınlatmaya çalışmıştır. Yazarın söylediklerinin çoğu ticari yönde olduğu için çalışmamızı pek ilgilendirmemekle beraber, oturumda Internet'te olup biten şeylere ilişkin ilginç göstergeler bulunduğunu vurgulamaktadır. O'Reilly şu 7 prensipten bahsetmektedir.

1. Altyapı Olarak Web: Bu altyapı Netscape'den Google'a doğru bir değişim göstermiştir. Netscape'in eski yazılım paradigmalarına dayanarak, bir platform olarak Web'le çerçevelenmesine karşın, Google'ın en önemli ürünü bir masaüstü uygulaması olan web tarayıcısı olmuştur. Örneğin, Google paketlenen veya satılan bir ürün olarak değil, bir web uygulaması olarak ortaya çıkmış ve bir hizmet olarak sunulmuştur. Bir diğer deyişle O'Reilly, "Google'ın, arama motoru ve içerik sunucusu ile tarayıcı arasında bir yerde bulunduğunu ve kullanıcılarla onların çevrimiçi deneyimleri arasında bir sağlayıcı veya aracı vazifesi” gördüğünü söylemektedir.

2. Ortak Akıldan Yararlanmak: Yahoo! ve Amazon, kullanıcıların ortaklaşa paylaştıkları bir alana taşınmakla, ortak akıldan yararlanma konusunda öncü olmuşlardır.

3. Kimler Veriye Sahiptir? Bu önemli bir sorudur: Veriye sahip olan kimlerdir ve bu kişiler, ellerindeki veriyi nasıl kullanacaklarına dair tercihlerini ne şekilde yapacaklardır? Bu sorular, veri ellerinde bulunanların zamanla ticari bir savaşla karşı karşıya kalacaklarını göstermektedir.

4. Yazılım Yenileme Döngüsünün Sonu: Eğer yazılım, kullanıcılara bir ürün değil de bir hizmet olarak ulaşırsa; o zaman bu türden yazılımlar hizmet sağlayıcılar üzerinde muazzam baskılar yaratan günlük işler temeline dayalı olarak sürdürülmelidir. O’Reilly, bu yeni 
paradigmanın kullanıcıların yardımcı web gelişimcileri gibi davranma gereksinimine yol açacağını ve bazı sitelerin neredeyse "devamlı beta" durumunda olacağını iddia etmektedir.

5. Alt Düzey Programlama Modülleri: Bundan önceki programlama modelleri, birleşik bağlantılı sistemlere izin verilmesi gerektiğini önermekte ve koordinasyondan daha çok içerik paylaşımına müsaade etmekteydi.

Tek Birim Düzeyinin Ötesindeki Yazılım: Yukarıdaki yazılım ilkelerini de gözeterek, herhangi bir birimde çalışabilecek yetenekte olan Web 2.0. yazılımına, özellikle hızıı bir şekilde oluşan hareketli bilgisayarlaşma alanında gereksinim duyulmaktadır.

6. Zengin Kullanıcı Deneyimi: Sonuç olarak, Web 2.0. kullanıcı tatmininin altın ödülü, bir ilkeden çok bir umut olarak görülebilir. Ancak bundan herkesin etkileneceği anlamı da çıkartılmamalıdır. Bunu British Daily gazetesinin Bilgi Teknolojileri Muhabiri Jack Schofield; yine The Guardian'ın aynı alandaki muhabiri; Amerikalı "Fog Creek Yazılım"ın Yönetim Kurulu Başkanı Joel Spolsky'den "Web 2.0. terimi beni özellikle rahatsı etmiştir. Bu gerçek bir kavram değildir. Anlamı yoktur. O büyük, şüpheli, salt mimari bir hiçliğin dumanlı bir toz bulutudur" (Schofield, 2005) yapılan alıntıyla anlatmaktadır.

\section{Web 2.0.'In Ögeleri}

Kullanıcılar açısından bakıldığında, Web 2.0.'ın en önemli bileşenleri sosyal etkileşimi de kapsayan;

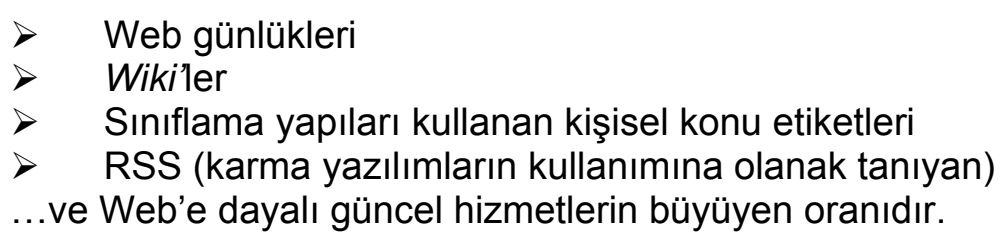

\section{Web Günlükleri (Blogs)}

Basit bir tanımla web günlüğü (blog), "çevrimiçi günlükleri veya sıklıkla güncellenen kişisel web sayfalarını içeren bir web (günlüğü) log'udur" (BlogsCanada.ca, 2003). Bir gazetecinin iddiasına göre günde 75,000 yeni web günlüğü üretilmektedir (Longbottom, 2006). Ayrıca IBM'in web güncelleme şefi ile yapılan görüşmede (Owen, 2006), "web günlüklerinin 
sayısı, (sadece aktif veya iyi olanlar değil) her beş ayda ikiye katlanmaktadır ve 2006'nın ortaları itibariyla 32 milyondan fazladır, hâlbuki 2003'de iki milyondan daha azdı. Barger "ekrana yazılan web günlüklerinin yüzde birinin değerli olduğunu" ileri sürmektedir. Web günlüklerinin iki temel kusuru bulunmaktadır. Birincisi, seyrek olarak güncellenmesi, diğeri girişlerin kronolojik olmasıdır, ki bu da, geriye dönük olarak kullanımda güçlük çıkartmaktadır.

Web günlüklerinin, neredeyse tamamının kişisel olmasından dolayı, beş türe ayrılarak yavaş yavaş geliştiği söylenebilir (Gotta, 2004):

$>\quad$ Kurum içi web günlükleri (sadece çalışanları hedefler)

$>\quad$ Kurum dışı web günlükleri (genelde halk üzerine odaklanır)

$>\quad$ Tematik web günlükleri (belli bir olay veya projeyle ilişkilidir)

$>$ Sponsorluk üstlenen web günlükleri (bir çalışan tarafından desteklenir, yetkilendirilir; ancak bir şirket tarafından onaylanması şart değildir)

Kişisel web günlükleri.

Bu listeden açıkça görüleceği üzere örgütler, bu teknolojiyi uyarlamaya başlamışlardır.

\section{Wiki'ler}

$\mathrm{Bu}$ sözcük, adını Honolulu Havalimanı'ndaki Wiki Wiki otobüs hizmetlerinden almaktadır ve çifte hız anlamına gelmektedir. Web terminolojisinde ise bu, "içeriğinin çok hızlı ve kolay bir şekilde, hatta kayıt olmaya bile gerek duyulmadan, kullanıcılar tarafından ekleme, düzeltilme veya kaldırılma yoluyla değiştirilebildiği, yani kullanıcıya bu olanağı tanıyan bir tür web sitesidir" (Wikipedia, 2007a).

Kesin olmamakla birlikte en ünlü wiki, Wikipedia'dır ve kısa tarihi Web 2.0. üzerindeki tartışmalarla açığa çıkmaktadır. Wikipedia, 1.5 milyon makaleyi içeren çevrimiçi ansiklopedi kayıtlarının (400 çevrimiçi gönüllüsünden) herhangi birisi tarafından düzenlenmesine ve/veya katkıda bulunulmasına izin vermektedir (Orlowski, 2006; Wikipedia, 2007b) Ünlü bilimsel dergilerden Nature'un araştırmasında, Wikipedia'daki 41 bilimsel makale gözden geçirilmiş ve bu makalelerde Britannica'daki 123 hataya karşın 162 hata bulunmuştur. Bu husus, Wikipedia'dan en son yapılan referanslarda da kapsamlı biçimde not edilmiştir. Britannica, konuyu hararetli bir biçimde tartışmıştır. Nature ise, kendi bulgularına fazla itibar etmedi.. Buna rağmen bazı Wikipedia 
eleştirmenleri, Wikipedia'nın ortak kurucularından Larry Sanger'in, "Citizendium" olarak adlandırdığı ve uzmanlar tarafından yazılan bir Wikipedia olan yeni bir çevrimiçi hizmetle ilgili planlarının olduğunu duyurdu (Moddy, 2006). Yine Wikipedia'nın ortak kurucularından Jimmy Wales yeni bir röportajında müthiş planlarının olduğunu söyledi. Bu planının tamamıyla şeffaf olacak bir arama motoruyla işbirliği çerçevesinde geliştirileceğini ve bu arama motorunda ticari avantajlar için sonuç verecek temayüllerin üretildiği algoritmaların olmayacağını duyurdu (Marks, 2007).

Bir gazetecinin belirttiği gibi, anonim wikilerle ilgili sorun, toplantıların "tamam, hadi wiki'yle ilgili tartışmalara devam edelim" sözleriyle bitirilmesi olmuştur ve bu daha önce aylarca kimsenin dikkatini çekmemiştir. Bu gazeteci, "wiki'yle ilgili işlevsel bir belge üretecek ve onu belli aralıklarla düzenleyebilecek eleştirel bir insan kitlesine gereksinim olduğunu" söylemektedir (Hogge, 2006).

\section{Kişisel Konu Etiketleri (Folksonomies)}

Etiket yapısı terimi, bir enformasyon mimarı olan Thomas Vander Wal tarafından üretilmiştir. Bu terimin Wikipedia (2007c)'daki karşılığı, "işbirliği ile üretilen web sayfaları, çevrimiçi fotoğraflar ve web bağlantıları gibi içeriklerle kategorize edilip, açık uçlu etiketlerden oluşan, İnternet'e dayalı bir bilgi erişim yöntemidir". Bu muhtemelen Web 2.0. tekniklerinin en tartışmalı yönüdür, çünkü Web 2.0. uzaktaki geniş kitleye cazip gelmesine rağmen, kütüphanecilerin ve bilgi bilimcilerinin de temel inanışına ters düşecek bir şekilde ortaya çıkmaktadır.

Vander Wal sadece üyelerin bulunduğu bir tartışma listesinde (IAI üyeleri tartışma listesi), etiketleme yapılarının, imkân olduğu sürece temiz tutulduğunda, 3 ögeden oluştuğunu söylemektedir:

> Etiketlenmiş obje: Vander Wal çoğu web günlüğünün, konu etiketlerinin yapılandırılmasında başarısız olduğuna dikkat çekmektedir. Çünkü hiçbir zaman günlük postasının mı etiketlendiği, hakkında yazılan olguların mı etiketlendiği, yoksa ikisi arasında bir şey mi yapıldığı açık değildir.

$>$ Etiketlerin kendisi

$>$ Kimliği

Wal, kişisel konu etiketlerinin, kontrollü sözlüklerle değil serbest etiketlendirme ile gerçekleştirilmesi gerektiğini eklemektedir. Etiketleme sorumluluğu ile ilgili çalışmalara, Hewlett Packard laboratuvarlarındaki 
araştırmacıların örneği verilebilir (Golder ve Huberman, 2006). Sonuç olarak yazarlar, "enformasyonun esasına göre büyük sayıda etiket yapmanın kamu yararından ziyade kişisel kullanımı hedef aldığını" söylemektedirler.

\section{Çeşitli Hizmetler}

$>$ RSS (Really Simple Syndication), "gerçekten kolay içerik paylaşımı", "zengin site özeti" (Rich Site Summary) ve RDF Kaynak Tanımlama Çerçevesi Site Özeti (Resource Description Framework), XML olarak belirtilen ve web içerik paylaşımları için kullanılan web formatındaki bir aile" olarak tanımlanabilir (Wikipedia, 2007d). Toplayıcılar (aggregators), bir zamanlar web sitelerini sıklıkla okuyanların onları güncelleştirmek için kullanmalarına izin vermekteydi (Wikipedia, 2007e).

$>$ RSS bir Mashup olarak nitelenen ve "tamamıla yeni hizmetler üretebilmek için birden çok kaynağın içeriğini kullanan web siteleri veya web uygulamaları" (Wikipedia, 2007f) anlamına gelen diğer araçlara izin verir. Google kendi Googlemap'i dâhilinde büyüyen bölge içerisinde beslenmektedir ve örneğin Chicago'da suçların işlendiği caddeleri Web'de gösterebilmek amacıyla polis tarafından kullanılmaktadır.

$>$ Podcasting "işitsel veya video programları gibi çoklu medya dosyalarının içerik paylaşımlarını kullanarak, onları İnternet aracılığıyla dağıtan yöntemdir" (Wikipedia, 2007g).

$>$ Ajax, (Asynchronous JavaScript ve XML), "etkileşimli web uygulamaları oluşturan bir web geliştirme tekniğidir" (Kynin).

Ve son olarak Bradley (2006), yeni Web 2.0. hizmeti aileleri hakkında aşağıdaki ifadeleri belirtmiştir:

$>\quad$ Çevrimiçi takvimler (RSS beslemeleri ile güncelleştirilmiş)

$>$ Kişiselleştirilmiş arama motorları (kişilerin ilgileri ve web sitelerine yönelik bireysel profilleri ile birlikte)

$>\quad$ Eşgüdümlü kelime işlemciler

Kuşkusuz, yıllar geçtikçe bu alanda çok daha fazla yenilikler ve ilerlemeler olacaktır.

\section{Girişimci Örgütlerde Web 2.0. Ögelerinin Kullanımı}

Örgütler aracılığıyla Web 2.0.'ın özelliklerini ele alan az sayıda resmi rapor vardır. Web 2.0. özelliklerini belli bir düzeyde kullanan girişimci bir 
örgüt European Investment Bankası'ndan Dresdner Kleinwort Wasserstein'dır. Bankanın şefi J.P. Rangaswami "çalışmalarına 1995'de wiki'yle başladıklarını ve 2002 'de onları web günlüğüne dönüştürdüklerini ve bunların daha kolay yönetilebilmesi için 2004'de birleştirdiklerini" (Burton, 2006) belirtmiştir. Konuyla ilgili deneyimlerin pek azı yayınlanmıştır. (Millen, 2005; Dodds, 2006 ve Wood, 2006). Bu raporların ilki, IBM'de "social bookmarking" araştırma prototipi üzerine yazılmıştır. Burada üç ilave teknik incelenmiştir: bunlardan birincisi, eklemelerdir. $\mathrm{Bu}$, bireysel etiket yapılarından elde edilen deliller aracılığıyla materyaller için uygun konu etiketlerinin ortaya çıkarılması amacıyla kullanılmaktadır ve öncülüğü büyük ölçüde Amazon tarafından yapılmaktadır. İkincisi bireylerin yer imlerini yine bireyler tarafından sağlanan diğer enformasyon kaynakları ile birleştirmektedir. Üçüncüsü ise, çeşitli takımlar veya projeler için sürdürülen web sitelerindeki bir grup bireyin sahip olduğu yer imi dermesidir. GM'nin sistem ve teknoloji şefi Fred Killeen, şöyle belirtmiştir: "Web 2.0.'ın materyallerle ilgili toplantıları desteklemeye dayalı wiki'nin kişisel konu etiketlerini, içsel yönetimin de işbirliğine dayalı çalışma için kullanılan terminolojinin tanımlarında ve özellikle resmi konu etiketlerinin oluşturulmasında yapılan harcamalardan kaçınmak üzere yoğun bir şekilde kullanmaktadırlar."(Saran, 2006). Rapor, bu masraflardan nasıl kurtulunabileceğine ve Web 2.0.'ın nasıl kullanılabileceğine yönelik açık ifadeler taşımamasına rağmen, taramada etkililik ve verimliliğin nasıl sağlanacağını karşılaştırması bakımından önem taşımaktadır.

Web 2.0. hizmetlerinin kullanılmasına ilişkin ticari basında birçok rapor ortaya çıkmasına rağmen, bunlar akademik dergilerde pek fazla yer almamaktadır. Andrew McAfee'nin MIT Sloan Management Review dergisindeki konuya ilişkin çalışmaları övgüye değerdir. McAfee (2006), "2.0. girişimci örgütlerdeki teknoloji uzmanları işin nasıl sınıflanması ve yapılandırıması gerektiğini önceden kavradıkları halde bunları empoze etmeye çalışmadıklarını; onun yerine bu tür oluşumlara imkan tanıyan araçlar oluşturduklarını" söylemektedir. Yazar, konuya ilişkin ilk harfleri S L A T E S (Search, Links, Authoring, Tags, Extension ve Signals) olan şu altı unsuru önermektedir.

Arama / Search: McAfee'nin arama motorlarının kullanılmasıyla ilgili çalışmalarından; taramadaki etkililik açısından yerel ağların, İnternet'ten daha geri kaldığı sonucunu çıkartabiliriz. Ancak bu karşılaştırmalar farkı kullanıcı gruplarının, farklı tarama ihtiyaçlarından dolayı sıklıkla yersiz ve 
geçersiz kalmaktadır. İnternet eğitimi için harcanan zaman ile yerel ağdaki özel amaçlı eleştirel enformasyonun aranması arasında büyük fark vardır.

Bağlantılar / Links: McAfee, Google tarafından bu alanda gerçekleşen ilerlemelerle övgüye değer bir noktada bulunulmakta olduğunu belirtmektedir. Oysa ki diğerleri, İnternet'i çekici yapanın hiperbağlantılar olduğu iddia etmekteydiler.

Yetkilendirme / Authoring: $\mathrm{Bu}$, muhtemelen web günlükleri ve wikiler aracılığıyla temel kullanım alanı sağlayan Web 2.0.'ın, en temel öğelerinden birisidir.

Etiketler / Tags: Web 2.0. temel öğelerinden birisi de, kişisel konu etiketleridir. Burada McAfee, ziyaret edilen yerel ağ ve İnternet sayfalarının etiket yapılandırmalarının gerçekleşebilmesi için çalışanların kullanıma dayalı yararlarını olduğunu tasavvur eder.

Genişletme / Extension: Burada McAfee, daha önce bahsedilen Amazon örneğini aktarmaktadır.

İşaretler / Signals: Çalışmanın başında belirtilen RSS besleme sistemi temel olarak ele alınmıştır. Aşırı enformasyon, yüklenimine ilişkin sorunlara yönelik saldırıların tasarlanması için vardır ve özelikle kurumsal ortamdaki arama motorlarının, nispeten güvenirliğinin olmadığı değişken durumlarda kullanılır.

McAfee'nin heyecanlı olduğu yerde, Tebutt (2006) girişimsel örgütlerde Web 2.0. uygulamalarının engellerinin ne olduğuna yönelik var olan makale listesine dikkat çekmektedir. Tebutt araştırmasında, sosyal bilişimi neden reddettiklerini açıklamadıklarının farkına vararak, analizcilerle, danışmanlarla ve sosyal bilişimcilerle konuşmayı tercih etti. Sonuçlar ilginçti ve şaşırtıcı değildi. Tebut'un analizi, şu beş temel başılı altında sunulmuştur:

1. Kaybedilen Denetim: Bu temel bir konu olmakla birlikte özellikle egemen firmalara yönelik olarak ortaya çıkmıştır. Bazı şirketler, çalışanlarına söz hakkı verdiklerinde tedirgin olurlar ve sosyal hesaplaşmanın hiyerarşiyi yıkacağına ve yönetimin gizli tutmayı tercih ettiği şeylerin çalışanlar tarafından keşfedileceğine inanırlar. Şirket politikaları ve prosedürleri üzerine davet edilen yorumların denetlenemeyen bir sel gibi akan zayıf bilgili yorumlara yol açabileceği yönünde bir korku vardır. 
2. Çalışanlara Asla Güvenme! Bu anlayış, önceki konuyla ilgilidir. Bazı şirketler çalışanlarının bu tür açık sistemleri etkili olarak kullanabilecek nitelikte olmadıklarını veya daha kötüsü, zamanlarını boşa geçireceklerini, ya da gizli bilgileri şirket dışına sızdırılabileceklerini düşünerek yeterince güvenmezler. Yazar bu çalışmasında çokuluslu bir şirkete, materyal teslim edilebilmesi için o şirketin ilgili biriminin avukatlarından izin alınması gerektiğini ve bu işin en az 3-4 hafta süreceğinin bilincinde olunduğunu vurgulamaktadır. Tebbutt, Forrester'in araştırma müdürünün "bu güven eksikliği, alfa tipli kıdemli erkek yöneticilerden dolayıdır., Bu yöneticilerin nelerinin iyi olduğu ve neye benzediklerinin denetlenmesi, ve yönetim kuruluna nasıl girdikleri kontrol edilmelidir." diye söylediğini nakletmektedir.. Bir şeyin kontrolünde olmak, onun neye benzediğinden ziyade nede iyi olduğu anlamına gelir, bu da onları başlangıca taşımak için bir çıkış noktasıdır.

3. Hepsini Daha Önce Duymuştum: Bir dizi yazar da, örneğin Gotta (2004), bu konu üzerine yorum yapmaktadır. Tebbutt tarafından alıntı yapılan bir BT yöneticisi, "siz, dağıtım listeleri, paylaşılmış klasörler ve e-odalar gibi diğer araçları işlevsel olarak birbirlerine yakınlaştırarak azaltamazsını" iddiasında bulunmaktadır. Ancak, bazı büyük içerik yönetim sistemcileri ve portal satıcıları, kendi portföylerinde web günlüğü ve wiki'yle ilgili işbirliği yapmaya başlamaktadırlar.

4. Sosyal Bilişimin Reddi: Değişim yönetiminin standart sorunu, çalışanları eski alışkanlıklarından ve fikirlerinden vazgeçirmek ve onlara yeni iş yöntemlerini benimsetmektir. Bazı teknolojik yeniliklerden bahsedildiği zaman ortaya çıkan yönetici soruları, "bundan bana ne, bu beni neden ilgilendiriyor" gibi standart sorulardır. Buna ek olarak, sosyal bilişimin açıklığı, kimi zaman değişim yönetiminin cesaretini kırabilir ve birçok değişim, çok gözönünde olduğu için çalışanları korkuya maruz bırakabilir.

5. Hiyerarşi Anarşisi: Birbirleriyle yakından ilişkili olan çalışanlarda denetim kaybı ve güven eksikliği özellikle orta düzey yönetime korku getirebilir ve böylelikle çalışanlar, eğer örgütlerdeki yaşamlarını daha kolaylaştıracaksa, resmi kanalları ve hiyerarşiyi gözardı ederler veya bundan heyecan duyabilirler. Böylece sosyal bilişim, örgüt içerisinde meydana gelen tamamlayıcı bir güç ağı 
halini alır. Bu konu kurumsal web günlükleri üzerine yapılan bir tartışmada bir bilgi yöneticisi tarafından özetlenmiştir. "Web günlükleri popülerdir, çünkü onlar kurumsal mesajlardan ziyade kişiliği ve kişisel fikirleri temsil etme eğilimi gösterirler. Bu yüzden, web günlüklerinin uygun kullanımından emin olmak için büyük özen göstermemiz gerekir. O halde, uygun kullanımı sağlayabilmek için büyük bir dikkatle web-günlüğünün değerini düşürmemeye özen göstermeli ve mesajların denetlenebilmesine yönelik temelde gereksinimimiz olanlardan kaçınmamamız gerekir" (McCue, 2006).

\section{Sosyal Bilişim}

"Ortak akıldan yararlanmak", O'Reilly (2005) tarafından ortaya atılan Web 2.0. ilkelerinden birisiydi ve Web 2.0'ın her türlü aldatmacanın ve ticari çıkarın ötesinde yer alan ve materyalist insanın düşünüşü ile enformasyonun demokratikleşmesi ve kişisel konu etiketlemesi (folksonomy) ve Citizendium gibi kavramların bir yansıması olduğuna şüphe yoktur. Bu öğeler ne anlama gelirse gelsin daima "sosyal" kelimesine yapılan bir vurgu vardır ve bu kelime, yüzeysel bir şekilde farklı anlamlara gelmesine karşın, kimi deyimlerin temelini oluşturur. Sosyal bilişimin "bilgisayar teknolojilerindeki etkileşimler ile kişiler ve onların sosyal davranışları arasında karşılıklı bir ağ yapısı etkileşimi", biçiminde geniş bir tanımı yapılabilir. Sosyal bilişimin daha özgün bir tanımı yapılacaksa, sosyal ağlaşmayı açıklamak gerekir. Sosyal ağlaşma, "web günlükleri, e-sohbetler, e-postalar, yoğun mesajlar ve video konferans gibi ağ hizmetleri kullanılarak arkadaşların veya işletmelerin birbirleriyle temas ettiği faaliyetler olarak tanımlanabilir. Sosyal ağlaşma açık sanal toplulukları veya kişinin kendi özel web sitelerini içerir". Etiket yapılandırılması ve kişisel konu etiketlerini kapsayan sosyal web-ayraçları ise, "kullanıcılar tarafından oluşturulan İnternet imlerinin paylaşılmış listelerinin görüntülendiği Web'e dayalı bir hizmet" olarak tanımlanabilir" (Wikipedia, 2007h).

Gotta (2004), "sosyal bilişimin ilgi alanını; işin, işgüçlerinin, iş derneklerinin ve işyerlerinin kendilerinin sanallaştırılması ve bunlara ilaveten iş ve yaşam tarzı arasındaki intiyaçlara yönelik sınırların giderek belirsizleşmesi ile oluştuğunu" söylemektedir. Bu yaklaşımın Schofield (2006) tarafından da vurgulanan ilginç bir yönü vardır. "IBM PC'den sonra, her yerde var olan işgücüne giren yeni bir kuşak vardır. Bunların çoğu, ev bilgisayarları ve oyunları ile avunarak büyütülmektedir. Çoğu kameralı telefonlar, sabit hatlı telefonlar, yoğun mesajlar, web günlükleri, 
yukarıda tanımlanmış bulunan "podcasting" yöntemi ve basit video konferansları için web kameraların kullanımı da bunlara en iyi örneklerdir". Bu araçların etkisi, girişimci örgütler açısından azımsanmayacak kadar önemlidir. Şu ana kadar Schofield, "işletmeler çoklu medyayı, pahalı bulduklarından ve özel eğitimli personele gereksinim duyulduğundan dolayı kullanma eğilimi göstermemektedirler" demektedir. Bir işin nasıl yapılabildiği bilgisine dayalı (know-how) bu yeni bakış açısı, modası geçmiş teknolojiler söz konusu olduğunda tatminsizlik getirmektedir. Buna en iyi örnek bilgi teknolojileri bölümünün, yöneticilerin ve kullanıcıların başağrısı olan e-postalardır (e-postaların \%70'inden fazlasının spam olduğu tahmin edilmektedir). J. P. Rangaswami tarafından Enterprise 2.0. uygulamalarından birkaçının mimarisi hakkında, "birkaç yıl daha olağanüstü amaçlara hizmet edebileceğinin öngörülmesine rağmen, şimdilerde e-posta çok yavaştır ve artık amaçlarla uyumlu değildir" (The e-mail killers, 2006) denilmektedir. En azından şimdilik, girişimci örgütlerde, yoğun mesajlaşma trafiği ve wikiler, modası geçmiş e-postalar halindedir. Bu tahmin, 2005 yılında Davenport'un (2005) yaptığı bir alan araştırması ile de güçlenmektedir. Davenport, bilgi işçileri tarafından oluşturularak kullanılan e-postaları aşağıdaki gibi göstermektedir:

$>\quad$ Bilgi işçilerinin \%26'sı örgütlerde e-postaların aşırı kullanıldığını,

$>$ Bilgi işçilerinin \%21'i e-postalar tarafından boğulduğunu,

$>$ Bilgi işçilerinin $\% 15$ 'i e-postaların üretkenliklerini gerçekten düşürdüğünü hissetmektedir.

$\mathrm{Bu}$ tatminsizlik düzeyinin azaltılabileceğine ilişkin herhangi bir alternatif süratle benimsenebilir. E-posta kullanımına yönelik yeni uygulama, yerel ağların yayıncılık mekanizmaları veya silolar tarafından üretilen veri tabanları yerine, gittikçe artan iletişim kanallarıdır.

\section{Çelişkiler ve Sonuçlar}

\section{Genel Yönetim ve Bilgi Yönetimi}

Önceki iki bölüm, sosyal bilişimle ilgili yönetim konularını ele almaktaydı ve bu konuların, girişimci örgütlerde Web 2.0. tekniklerinin uygulanmasına ilişkin ne gibi yararlar getirdiğini tartışmaktaydı. Açıkça görülmektedir ki, kimi girişimci örgütler, diğerlerine göre daha ikna edilebilir olmaktadır. 
Buradan hareketle, örgütlerde sosyal bilişimden yararlanarak diğerlerine nazaran daha fazla yarar sağlayan özgün gruplar vardır ve bunlar hayli şaşırtıcıdır. Konuyla ilgili olarak Brown ve Duguid (2001) "büyümek için yaşamsal olan yeni bilgi, sıklıkla küçük topluluklar tarafından oluşturulmaktadır" ifadesini kullanmaktadır. Diğer bir deyişle, araştırma grupları sıklıkla, bir dizi ortak alışkanlıklar, gelenekler veya görenekler, yetkeler ve yaklaşımlar geliştirmektedir. Bunlar, örgütlerin hem yeni bir anlayış üretmelerine hem de dışarıdakilere bu türden yeni bilgilerin nasıl transfer edilebileceğine yönelik imkân vermektedir". Bu dolaylı ve şaşırtıcı olmayan önermeler, uygulama toplulukları veya sosyal bilişimden kâr sağlayacak veya onu benzer bir biçimde kullanabilecek örgüte yerleşmiş çıkar topluluklarından meydana gelmektedir. Yazarlara göre, "herhangi bir örgütün kendine özgü belli gelişme aşamalarına ulaştığı ve ancak (bir kuartetinkine benzer) kendi kendine örgütlenme yerine, bölümleri arasında (orkestra şefine gereksinim duyan) bir orkestra gibi olduğu zaman, iş süreçlerinin uygun şekilde yapılandırılması önem taşımaktadır. Süreç, farklı toplulukların işbirliğine yardımcı olur ve böylece ilerlemeye açık uygulamalar, bir diğerini etkilemeden büyüyemez. İdeal olarak uygulama süreçleri özenli fakat aynı zamanda esnek yapıda olmalıdırlar, Bu dengenin başarılması kolay değildir. Süreç, örgütlerin komut ve kontrol hiyerarşisini esas almaktadır.. Buna karşın uygulamada gerçekleştirilen, içsel eşgüdüm ve neyin yapılacağını belirlemektir. Süreçsiz bir uygulama, yönetilemeyen bir eğilim göstermekte; uygulamasız bir süreç ise sürdürülebilir bir yenilik için gerekli olan yaratıcılığın kaybı ile sonuçlanmaktadır.

\section{Bilgilenen Liderlik ve "Kitlelerin Bilgeliği “}

İnternet sitesinin etiketlenmesiyle, konusunda İnternet-sevdalısı bir kişi tarafından ortaya atılan argümanlardan birisi, katkıda bulunacak daha fazla insan, doğru bilgiye varacak daha fazla kişidir. Campbell ve Fast (2006) bu konu hakkında en açık belirlemeyi aşağıdaki şekilde yapmışlardır:

$>$ Eğer (sayfalararası bağlantılar yapma, etiketleme, paylaşma veya aboneleştirme gibi) ne yapacaklarını bilen yeteri kadar insana sahipsen, ilginç ve faydalı örüntüler oluşur.

$>\quad$ Bu örüntüler, işe daha fazla insanın katılmasıyla daha ilginç ve faydalı olur.

$>\quad$ Bu örüntüleri kullanan sistemler, kütüphane katalogları gibi geleneksel bilgi sistemleriyle yapılamayacak kadar daha geniş ölçeklerde çalıştırılabilir.

> Sistemler, daha az kural ve sınırlamalar ile daha fazla benimsenmeyi ve daha faydalı örüntülerin meydana getirilmesini sağlayacaktır. 
Bu çalışma bağlamında, "onların ne istediği" ve "daha az kurallar ve sınırlılıklar" ifadeleri göze çarpmaktadır.

Nature dergisinden orijinal olarak yapılan alıntıda "yeteri kadar insan" vurgusu önemlidir ve sık sık etiketleme yapılarının unsurları aracılığıyla ifade edilmektedir. İngiliz bilgini Francis Galton (1907), biçimsel olmayan ve küçük deneyimlerin 20. yüzyılın başlarında kaldığını belirtmektedir. Galton, bir ineğin ağırığının tahmin edilmesine yönelik 787 katılımcı toplar. Katılımcılar; çiftçiler, kasaplar ve seyircilerden oluşan bir karmadır. Galton, verilen cevapların ortanca ve ortalama tahminlerinin aldı. Ortanca, doğru cevap ağılıklarının \%8'i, ortalama ise $\% 0.01$ 'i olarak tahmin edildi. Bu ilginç deneyimde bir dizi faktör önemliydi. Birincisi, muhtemelen belli bir konuya yönelik kurumsal wiki veya web günlüklerine üye olanlardan daha fazlası bu araştırmaya dâhil edilmişti. İkincisi Galton, soyut konular hakkındaki düşüncelerden değil, geçerliliği kanıtlanabilir gerçeklerden hareketle verilecek cevaplara odaklanmıştı. Bir benzetimle, web günlükleri de bireylerin, kendi tercih. ve kişiliklerine yönelik yanıtları toplayabilir.

$\mathrm{Bu}$ soyut konular hakkındaki fikirler ile gerçek sorulara verilen tahmini yanıtlar arasındaki fark, pek tabii ki inanılmazdır ve yine bir benzetimle karmaşık konulara yönelik halk referandumunda en açık bir şekilde yer almaktadır. Ancak sorun örgütsel bağlamın birisine işaret etmektedir. Önceki paragrafta tırnak işareti içerisinde yapılan atıftan açıkça görülmektedir ki, fikirler, özelikle topluluk üyeleri tarafından sadece uygulama alanında memnuniyetle karşılanmaktadır. Ancak yine bu fikirler, süreç alanındaki kıdemli yöneticiler açısından daha az memnuniyet vericidir. Nispeten daha az kıdemli olan çalışanlar tarafından yine bu fikirler, bireysel bağlam içerisinde beyan edilmekte, bir dizi gerçekleri kapsamakta ve önceki fikirler yine bu bireyler tarafından elde edilmektedir. Bu gerçekler, yönetim kurulu üyelerininkinden de çok farklılaşmaktadır. Çalışanlarının çoğundan oluşan uzlaşı fikri, işgücünün gidişatı hakkında kıdemli yöneticilere güçlü bir sinyal olarak gönderilebilir, ancak bu her zaman işletmecilikte değerli bir hedef olarak görülmeyebilir.

\section{Bilgi Yönetimi ve Enformasyon Yönetimi}

Herkesin de bildiği gibi, yönetim düşüncesinin yeni ve ilgi çekici fikirlerin moda dalgasına bağlı olarak ortaya çıktığı söylenebilir, ancak mevcut durum yerine yeni bir dalga olarak desteklenmesi hatalı olacaktır. Web 2.0.'ın, Web 1.0.'ın yerini alacağı belli değildir; Web 1.0.'ın kimi 
özelliklerini içereceği ve büyük oranda İnternet özelliklerini kapsayacağı düşünülebilir. Web 2.0.'ın, Web 1.0.'ın yerine geçme olasılığı az da olsa, bilinen İnternet özelliklerinin içerisinde olacağı bir gerçektir. "Enterprise 1.0.'ın yerini Enterprise 2.0. almayacaktı" açıklamasını destekleyen muhtemelen güçlü savlar vardır. Bazı yazarlar, en azından, kütüphane sınıflama sistemleri ve web sitesi sınıflamaları gibi formel sistemlerin yerini, etiketleme ve kişisel konu etiketlemelerinin alabileceğini düşünmektedirler. Ancak ne yazık ki bu tür sınıflamaların oluşturulması ve sürdürülebilmesi pahalıdır. Ancak McGregor ve McCullough (2006) vurguladıkları gibi, "ilginçtir ki, bu dönem sırasında ortak etiket yapıları oluşmakta ve buna paralel olarak denetlenmiş sözcük öbeklerinin yeniden doğrulanması konusu meydana çıkmaktadır. Kurumsal sektör içerisinde gelişmiş enformasyon düzenlenmesi ve yönetiminin gerekliliği, kurumsal sınıflamaların gelişimini ve örgüt içerisine yerleşimini kolaylaştırmaktadır".

Açık bir şekilde ifade edildiği gibi sosyal bilişim, bilgi yönetimini destekleyen bir araçsa, o zaman bunun desteklenmesine gereksinim vardır ve daha resmi bilgi yönetimi yöntemleriyle bütünleştirilmelidir. Nonaka ve Takeuchi (1985) tarafından bilginin dönüşümüne yönelik dört tür önerilmektedir:

$>\quad$ Sosyalleşme: Örtük bilgiden örtük bilgiye

$>$ Dışsallaştırma: Örtük bilgiden açık bilgiye

$>\quad$ Kombinasyon: Açık bilgiden açık bilgiye

$>\quad$ İçselleştirme: Açık bilgiden örtük bilgiye

Bu dönüşüm dengeli ve bütünleştirici bir biçimde tasarlanmalıdır.

\section{Aşırı Enformasyon ve Teknoloji Yüklenimi}

Son çelişki, kısmen aşırı bilgi yüklenilmesine iliş̧in tartışmalara katkıda bulunacak yeni teknolojiler gerçeğinden meydana gelmektedir. Daha ileri olarak, dikkatli olmadıkça bu teknolojilerin gerçekten ikinci derecede önemli enformasyona katkıda bulunacağı kesin değildir. Lordlar Kamerası'ndan Baroness Greenfield, çocuk eğitimi ile ilgili bir çalışma üzerine daha çok uygulamaya dayanan bir rapor üzerinde, sonuçların daha kapsamlı olduğunu belirten bir konuşma yapmıştır. (UK Parliament. Publications \& Records, 2006). Rapor, 8-18 yaş arası çocukların günlük ortalama $6 \frac{1}{2}$ saatini elektronik medya kullanımında harcadığını göstermekte ve şu şekilde sonuçlanmaktadır: "Ekran kültürü, sonsuz ses parçalarının, hızlı görüntü atlamalarının ve olgunlaşmamış fikirlerin 
yoğun akışının olduğu bir dünyada bulunmaktadır. Ekran kültürü, dedikoduya dayalı haberlerin akışı, haber başlıkları ve konuya ilişkin ilk izlenimlerin ortaya konulduğu bir kültürdür. Burada fikirler tek başına olmazlar, ancak yoğun bir şekilde her şeyle bağlantılıdırlar; burada doğruluk, yazarlar veya otoriteler aracılığıyla iletilmez, ancak dinleyiciler tarafından monte edinmeğe çalışılırlar ". Eğer bu olgu, gittikçe artan rekabetçi ve hızla değişen iş dünyasında da kendisini yinelerse, o zaman akıl yürütmek ve dengeli kararlar almak için az zaman kalması tehlikesi vardır. Hal böyle olunca, talep edildiğinde teknoloji kullanımındaki ve tasarımındaki denge de önemli hale gelecektir.

Sonuçlar aşağıdaki gibi özetlenebilir:

- Web 2.0. olarak bahsedilen yeni teknoloji dalgaları hiç kuşkusuz evrim geçirecek ve gelişecektir.

- $\quad$ Buna karşın; Web 2.0.'a dayalı teknolojiler, uygulamada tüm işletmeler için gerekli ölçüde uygun olacaktır.

- $\quad \mathrm{Bu}$ teknolojilerden bazıları belli sektörlerdeki girişimci örgütler hatta özellikle topluluklar için faydalı olacağı varsayılmaktadır.

- Dolayısıyla bilgi yönetimi ilkelerinin genişletilmesi nispeten de olsa, daha iyi anlaşılacaktır.

- $\quad$ Bu teknolojileri geniş bir biçimde kapsayacak herhangi bir girişim veya dikkatli hazırlanmamış planlar, başarısızlığa mahkûm olacaklar ve verimsiz kalacaklardır.

- En azından bu türden teknolojilerin benimsenmesine, işgücüne dayatılmasından çok kendi doğal süreci içerisinde yavaş yavaş uyarlanmasına olanak tanınmalıdır.

- Web 2.0.'ın kolaylıklarının aynı işlerde tekrarlanmalarından kaçınılmalıdır. Kullanıcıların düşünceleri, sunulan teknolojilerin yeterince farklılaşamamaları nedeniyle kolayca karışabilir.

- $\quad \mathrm{Bu}$ teknolojiler sınanmadan reddedilmemelidir. Hâlihazırda eğer bu olanaklar özgün ihtiyaçlar ve durumlar yönünde değiştirilebilirse faydalı olabilirler.

- $\quad$ Teknoloji her nerede uygulanırsa uygulansın, formel bilgi sistemleri ile birleştirilmeli ve desteklenmelidir. 